\title{
STARSZE KOBIETY I ICH DUCHOWOŚĆ W KSIĘDZE TOBIASZA
}

DOI: http://dx.doi.org/10.12775/TiCz.2017.054

Niewiastę dzielną któż znajdzie? Jej wartość przewyższa perły. Kłamliwy wdzięk i marne jest piękno: chwalić należy niewiastę, co boi się Pana.

(Prz 31,10.30)

\section{WSTĘP}

„Niewiastę dzielną któż znajdzie?” (Prz 31,10) - Każdy, kto otwiera Stary Testament! ${ }^{1}$ Jego karty ukazują, że kobiety miały udział w przymierzu z Bogiem, a także odgrywały aktywną rolę w historii zbawienia. Jednak rola kobiet z czasem została nieco zakryta, począwszy od reformacji,

* Irmina Nockiewicz - doktorantka na Wydziale Teologicznym UKSW w Warszawie (Katedra Teologii Życia Duchowego), prowadzi badania nad duchowością osób świeckich (i.nockiewicz@gmail.com).

1 I. Nowell, Roles of Women in the Old Testament, http://www.laici.va/content/ dam/laici/documenti/donna/bibbia/english/roles-women-old-testament.pdf, [dostęp: [dostęp: 28.02.2017]. http://www.laici.va/content/dam/laici/documenti/donna/bibbia/ english/roles-women-old-testament.pdf [dostęp: 28.02.2017]. 
która odrzucając niektóre księgi biblijne, odrzuciła zarazem takie postaci jak Judyta, Zuzanna czy bohaterska matka Machabejka, a skończywszy na radykalnym feminizmie, chcącym widzieć kobiety w roli mężczyzn². Warto sobie uzmysłowić, że na kartach Pisma świętego obraz kobiety uosabiał naród wybrany i jego relację z Bogiem, już to ukazując Izraela jako niewierną wybrankę i małżonkę Boga $(\mathrm{Oz})$ lub też ukaraną, niepocieszoną córkę, czy żonę, bezdzietną lub owdowiałą (Iz), a w końcu jako personifikację mądrości (Prz) ${ }^{3}$.

Zaskakujący w dzisiejszych czasach może okazać się fakt, że starotestamentalny poemat o dzielnej niewieście nie sławi aktualnie promowanego ideału kobiecości: młodej, pięknej, inteligentnej, wysportowanej i niezależnej, ale za wzór stawia kobietę zamężną, doświadczoną, matkę wielu dzieci, można więc śmiało przypuszczać, że nie najmłodszą, a może nawet starszą, steraną życiem oraz tym, co ono ze sobą niesie, a w dawnych czasach niosło wiele więcej trudu niż dzisiaj, chociażby z powodu braku rozwiązań technicznych idących w parze $\mathrm{z}$ rozwojem cywilizacji (np. elektryczności, kanalizacji etc.). Skoro więc Pismo święte stawia na świeczniku kobietę w wieku średnim, żonę i matkę, która oddana rodzinie i sprawom domu ciężko pracuje, stąd też w niniejszej pracy zostanie podjęty temat obrazu takiej kobiety. Badanie zostanie przeprowadzone na księdze Tobiasza, która dzięki walorom literackim narracji i charakterystyki postaci ukazuje miejsce i rolę, jaką odgrywały w społeczeństwie kobiety starsze oraz ich duchowość, która wpisuje się w szerszy przekaz teologiczny tej księgi.

Tłem księgi Tobiasza są dzieje społeczność diaspory izraelskiej w Imperium Asyrii i Medii, po deportacji plemienia Neftalego do Niniwy, stolicy Asyrii (VIII w. przed Chr.), samą księgę datuje się zaś na IV w. przed Chr., kiedy tereny te zamieszkałe były przez Persów (dzisiaj to tereny Iraku i Iranu) ${ }^{4}$.

2 C. Brown Tkacz, Are Old Testament Women Nameless, Silent, Passive Victims?, „This Rock” 17 (2006) 10, źródła internetowe: http://www.catholic.com/magazine/articles/ are-old-testament-women-nameless-silent-passive-victims [dostęp: 28.02.2017].

3 J. Slawik, O rolach kobiet w Starym Testamencie (Biblii Hebrajskiej), „Rocznik Teologiczny ChAT” 54 (2012) 1-2, s. 11.

4 B. Proc, Wpływy perskie $w$ księdze Tobiasza, „Scripta Biblica et Orientalia” (2011) nr 3, s. 183. 
Księga charakteryzuje się osadzeniem w środowisku rodzinnym i ukazuje troskę o bliskich. Tobit i Hanna są lojalnym małżeństwem, zmagającym się z trudami życia. Ich główną troską jest religijno-moralne wychowanie syna oraz jego przyszłość finansowa i małżeńska. Podobnie Raguel i Edna, jako dobrzy rodzice, troszczą się o swoją jedynaczkę, która z powodu dramatycznej sytuacji życiowej ma myśli samobójcze. Bohaterowie księgi są przykładem przyjaźni, wierności, gościnności, zaufania, odwagi i wytrwałości ${ }^{5}$. „Portrety charakterologiczne bohaterów są wyraziste: zasadniczy Tobit, zgryźliwa Hanna, niepewny Tobiasz, energiczny i kompetentny Azariasz, depresyjna Sara, fatalistyczny i solenny Raguel. Są oni ludźmi dobrymi, choć nie bez wad"6.

Protagoniści księgi Tobiasza są spokrewnieni i mimo cech indywidualnych występują wspólnie, w kontekście rodziny, gdzie kobieta z natury rzeczy odgrywa znaczną rolę, a także w szerszej perspektywie społeczności wspólnoty narodowej. Dzięki księdze Tobiasza można poznać zadania kobiety, uwarunkowania jej życia, trudności, a nawet dotrzeć do pewnych aspektów jej życia uczuciowo-relacyjnego i czynności kultycznych przez nią sprawowanych. Warto przy tym zauważyć, że narracja, ukazująca zarówno mężczyzn, jak i kobiety w osnowie więzi rodzinnej, jest powodem, dla którego dzisiejsza feministyczna interpretacja księgi Tobiasza, skupiająca się na indywidualnej roli kobiet, jest nietrafiona ${ }^{7}$.

Księga Tobiasza traktuje głównie o sprawach małżeństwa i rodziny, która będąc spoiwem życia społecznego, jest tutaj także miejscem rozgrywania się losów bohaterów ujętym w szerszym kontekście społecznym wspólnoty diaspory izraelskiej, która stara się o przetrwanie, tj. zachowanie własnej tożsamości kulturowej i wiary w Boga ${ }^{8}$. W niniejszym opracowaniu odniesiemy się do dwóch opisanych wcześniej par małżeńskich, które stanowią bohaterowie fabuły Tobit i Hanna oraz Raguel i Edna, a także zajmiemy się parą, która pojawia się w tle historii (Debora

${ }_{5}$ M. Wojciechowski, Nauczanie moralne greckich ksiag Starego Testamentu, „Analecta Biblica Lublinensia” 7 (2011), s. 101.

${ }^{6}$ M. Wojciechowski, Ksiega Tobiasza, czyli Tobita. Opowieść o miłości rodzinnej, Częstochowa 2005, s. 26.

7 Tamże, s. 43-45.

${ }^{8}$ W. Linke, Literacka ojczyzna Tobiasza. Tło kulturowe Tb jako klucz teologicznej lektury księgi, Warszawa 2013, s. 55. 
i Aduel), ale nie bierze w niej udziału. Naszą uwagę poświęcimy konkretnie trzem kobietom: Deborze, Hannie i Ednie, nie będziemy natomiast zajmować się Sarą, bohaterką głównego wątku, ani postaciami męskimi.

\section{DEBORA, BABKA TOBITA}

Kobiety w Biblii hebrajskiej najczęściej pojawiają się jako rodzące dzieci (ponad 400 razy), są więc przedstawiane przede wszystkim jako żony i dobre matki, a przed zamążpójściem jako posłuszne córki ${ }^{9}$, podobnie w księdze Tobiasza są one wpisane w kontekst małżeński. Pierwsza wymieniona w tej księdze jest Debora, żona Aduela, matka Ananiela, babka Tobita (por. Tb 1,8) ${ }^{10}$. Debora („pszczoła” ${ }^{11}$ ) jest tylko wspomniana, z szacunkiem należnym przodkom, nie jest jednak bohaterką rozgrywającej się w księdze akcji. Nosi ona imię bohaterskiej kobiety, która była żoną Lappidota i pochodziła $\mathrm{z}$ plemienia Naftalego ${ }^{12}$, tego samego, co ród Tobiadów. Patronka babki Tobita, Debora, była prorokinią i pełniła urząd sędzi. Ona zachęcała Baraka do zwycięskiej walki przeciw Siserze, dowódcy armii kananejskiego króla Jabina. Imię Debora podkreśla godność babki Tobita oraz wskazuje na ród Neftalego. Główną zasługą babki jest zatem pochodzenie, takie ujęcie tematu wskazuje na androcentryzm rodziny. Brak wzmianek o matce Tobita, nie wiadomo, czy zmarła, czy też żyje, nie ma również mowy o jej rodzinie. Z perspektywy androcentrycznej matka Tobita nie jest ważna i nie ma żadnego wpływu na wychowanie syna, stąd nie jest nawet wspominana ${ }^{13}$.

Inne zasługi babki Tobita, chociaż są wymienione, mają wartość drugorzędną. Debora jest ukazana także jako nauczycielka prawa Mojżeszowego. „Trzecią [dziesięcinę] dawałem sierotom, wdowom i prozelitom, którzy należeli do synów Izraela. Myśmy ją jedli stosownie do podanego w Prawie Mojżeszowym przepisu i stosownie do zaleceń Debory, matki

9 J. Slawik, O rolach kobiet, dz. cyt., s.11.

${ }^{10}$ W. Linke, Literacka ojczyzna, dz. cyt., s. 56.

11 J. Balldock, Kobiety w Biblii, Warszawa 2008, s. 81.

12 Por. I. Zielonka, Kobiety stawione pieśnia w Starym Testamencie - Debora i Jael, „Collectanea Theologica” 81 (2011) 1, s. 17-39.

13 W. Linke, Literacka ojczyzna, dz. cyt., s. 80. 
Ananiela, mojego ojca, ponieważ ojciec mój umarł pozostawiając mnie sierotą" (Tb 1,8). Dzięki otrzymanemu w domu wychowaniu religijnemu Tobiasz podejmuje czyny miłosierdzia, to jest jałmużnę. Użyty tutaj grecki termin $\dot{\varepsilon} \lambda \varepsilon \eta \mu \sigma \sigma v ́ v \eta^{14}$, występuje w księdze Tobiasza aż 22 razy dla opisania intymnego, przepełnionego wzruszeniem uczestnictwa w dramacie drugiego człowieka z powodu sytuacji trudności i cierpienia, w jakiej ten się znalazł i jest rozumiane jako miłosierdzie, które może być zarówno cechą boską lub ludzką ${ }^{15}$. W omawianej księdze miłosierdzie jest często synonimem jałmużny pieniężnej lub dawanej w naturze, np. jako posiłek dla nakarmienia głodnych. Chociaż księga Tobiasza w wielu miejscach traktuje o jedzeniu i jego przygotowaniu ${ }^{16}$, to jednak w tej krótkiej charakterystyce odsłania się wymiar kultyczny spożywania posiłku odnoszący się do sfery domostwa oraz wyraźnie stojący w opozycji do wymienionego dalej spożywania chleba pogan - tj. Niniwitów, wśród których żyła opisana diaspora, mającego negatywną kwalifikację moralną.

W judaizmie część przepisów regulowała podstawowe czynności życiowe, m.in. jedzenie. W optyce biblijnej pokarm nie jest własnością człowieka, ale darem Stwórcy, i na znak tego człowiek był zobowiązany do ofiarowania części pokarmu Bogu. Sprawowanie kultu w wykonaniu kobiecym odnosi się do pożywienia, a więc do sfery domowej. Kobietę uważano za naturalnie przeznaczoną przez Stworzyciela do karmienia, gdyż własną piersią karmi swoje dzieci. Na żydowskiej kobiecie spoczywała zatem odpowiedzialność nie tylko za przygotowanie pokarmu, ale także za jego uświęcenie, stąd też jej obowiązkiem było poznanie swojej roli poprzez badanie Tory. Obowiązki przypisane kobietom przez Biblię są „micwot domowymi”, dlatego też kobieta jest bardziej obecna w domu niż poza nim, chociaż formalnie nic nie stoi na przeszkodzie, aby Żydówka

${ }^{14}$ M. Wojciechowski, Księga Tobiasza, czyli Tobita, dz. cyt., s. 47, 56-60, 83-84.

15 W. Przygoda, Miłosierni jak Ojciec. Teologia i praktyka miłosierdzia chrześcijańskiego, w: Współczesne wyzwania Teologii Pastoralnej, red. R. Chałupniak, J. Kostorz, Opole 2016, s. 12.

${ }^{16}$ N. Jackobs, You did not hesitate to get up and leave the dinner - Food and eating in the narrative of Tobit with some attention to Tobit's Shavuot Meal, w: The book of Tobit: Text, Tradition, Theology, red. G. G. Xeravits and J. Zsengellér, Pápa 2004, s. 121-138. 
wykonywała pracę poza domem, jednak mogłoby to odciągać ją od zaangażowania w wykonywanie obowiązków specyficznie jej przypisanych ${ }^{17}$.

Wychowanie otrzymane $\mathrm{w}$ domu jest szkołą sprawiedliwości, rozumianej jako wypełnianie prawa bożego i miłosierdzie. Jednak, jak to już zostało zasygnalizowane wcześniej, wspomnienie babki nie tyle jest związane z chwalebną patronką, czy nawet jej wzorcową pobożnością, której uczyła wnuki, co wynika z faktu jej związku z ojcowską gałęzią rodziny, której szlachetność ma podkreślać właśnie szlachetna przodkini oraz kult Boga i dobroczynność.

\section{HANNA, ŻONA TOBITA I MATKA TOBIASZA}

Kolejną kobietą w Księdze Tobiasza jest Hanna, pochodząca z tego samego rodu, co Tobit, który wziął ją za żonę, kiedy osiągnął wiek męski $(\mathrm{Tb} 1,9)$. Hanna, Anna (Channa) są to imiona pochodzące od hebrajskiego chanan - 'okazać łaskawość, zlitować się i pojawiają się w Biblii w formie różnych imion, np. Chanan - 'łaskawy' (Jr 35,4); Chananel - 'łaska Boża, Bóg jest łaskawy' (Jr 32,7); Chananiasz - 'Jahwe jest łaskawy' (Jr 28,1; gr. Ananiasz, Dz 9,10-18) ${ }^{18}$.

Pierwszą informacją charakteryzującą Hannę - oprócz imienia jest małżeństwo i to zawarte zgodnie z zasadami endogamii, skąd bierze się nazywanie jej przez Tobita siostrą, zwrot ten podkreśla także trwałość związku (zob. np. Tb 5,22; 7,11) ${ }^{19}$. Pochwałę praktyki endogamicznego przymierza małżeńskiego znajdujemy oprócz księgi Tobiasza również w innych miejscach Starego Testamentu (np. Jdt, Ezd, $\mathrm{Ne}^{20}$ ). Małżeństwo według autorów biblijnych jest prawidłowym stanem osób dorosłych,

17 E. Limentani, Il Ruolo della donna nella tradizione ebraica. Beve panorama storico-sociale, źródła internetowe: http://www.babelonline.net/home/003/ventaglio/Limentani_rulo_donna.pd [dostęp: 28.02.2017].

18 Z. Ziółkowski, Z najtrudniejszych, dz. cyt., Warszawa 2006, s. 777; R. Bauckham, Tobit, as a parable for the exiles of Northern Israel, w: Studies in the Book of Tobit: A Multidisciplinary Approach, red. M. Bredinss, London 2006, s. 151.

19 M. Wojciechowski, Księga Tobiasza, czyli Tobita, dz. cyt., s. 43-44.

${ }^{20}$ W. Linke, Literacka ojczyzna, dz. cyt. s. 71-74; por. W. Linke, Małżeństwo Tobiasza i Sary w księdze Tobiasza. Przyczynek do historii instytucji matżeństwa, „Collectanea Theologica" 79 (2009) 4, s. 31-45. 
jego archetypem jest zaś związek Adama i Ewy. Wyjątkowa komplementarność mężczyzny i kobiety ma swoje źródło w akcie stwórczym, jednak swoją pełnię osiąga w małżeństwie, które w księdze Tobiasza jest monogamiczne, wierne i nierozerwalne, perspektywą zaś sięga wspólnego starzenia, a nawet pochówku małżonków obok siebie ${ }^{21}$. Małżeństwo wyrażało zatem stwórczą moc Boga, a nie kult płodności, z czym mamy do czynienia $\mathrm{w}$ religiach pogańskich ${ }^{22}$. Rodzina w kulturze hebrajskiej jest głównym czynnikiem tworzenia tożsamości jednostki i narodu oraz podstawową komórką życia obrzędowo-religijnego. Zawarcie małżeństwa, którego formuła w księdze Tobiasza brzmi: „Weź więc swoją siostrę! Od teraz ty jesteś jej bratem, a ona twoją siostrą. Jest ona dana tobie od dziś na zawsze" (Tb 7,12), nie miało charakteru kultycznego, ale raczej społeczny i było określane mianem przymierza. Akt małżeński był spisywany, a istotną częścią małżeństwa była przeprowadzka do domu męża. Małżonkowie wraz z dziećmi wpisywali się w koncentryczną strukturę rodziny wielopokoleniowej, tworzącej rody po linii męskiej, a w końcu naród. Do wspólnoty rodzinnej zaliczano niekiedy także niewolników, służbę oraz gości ${ }^{23}$.

Głową rodziny żydowskiej był ojciec - patriarchat był rozpowszechnionym modelem rodzinnym w starożytności, nie inaczej jest w księdze Tobiasza ${ }^{24}$. Chociaż Hanna przedstawiona jest jako osoba lękliwa, obawiająca się o swoją przyszłość, z konieczności więc poddana przewodnictwu męża, to jednak w księdze Tobiasza można dopatrywać się śladów tzw. półpatriarchatu, gdyż matka czuje się jednakowo odpowiedzialna za los dziecka, jakby do niej przynależało w pewien sposób, co nie

${ }^{21}$ M. Wojciechowski, Księga Tobiasza, czyli Tobita, dz. cyt., s. 43-44, 83, 108.

${ }^{22}$ E. G. Skóra, Seksualność człowieka jako mężczyzny i kobiety na tle Starego Testamentu, „Kwartalnik Naukowy Towarzystwa Naukowego Fides et Ratio” 4 (2014)20, s. 12; por. W. Chrostowski, Rzeczywistość i symbolika kobiety w Biblii, „Pastores” 14 (2002) 1, s. 9-21.

${ }^{23}$ T. Twardziłowski, Zarys problematyki rodzinnej $w$ Biblii, w: Instytucja rodziny wczoraj $i$ dziś - Perspektywa interdyscyplinarna, T. 2: Społeczeństwo i kultura, red. J.K. Stępkowska, K.M. Stępkowska, Lublin 2012, s. 112.

${ }^{24} \mathrm{M}$. Rose, Une herméneutique de l'Ancien Testament: comprendre, se comprendre, faire comprendre, Genewa 2003, s. 228. 
jest kwestionowane $(\mathrm{Tb} 5,18)^{25}$. Nie ulega wątpliwości, że matce należał się szacunek, uzasadniany trudami ciąży, taka argumentacja dowodzi zrozumienia sytuacji kobiet, którym nie zawsze udawało się przeżyć poród.

Ojciec reprezentował rodzinę na zewnątrz i zarządzał całym majątkiem rodziny. Żona stanowiła niejako własność męża. W dekalogu zakaz pożądania cudzej własności jest uściślony, żona zaś jest wymieniona na równi z niewolnikami, inwentarzem i dobytkiem. W innych księgach Starego Przymierza znajdujemy nawet świadectwa sprzedaży żony (np. Rdz 12), a prawodawstwo Bliskiego Wschodu mówi też o sprzedaży dzieci² ${ }^{26}$, stąd możliwość ich utraty wraz z całym majątkiem, co mogło spotkać również Tobita, kiedy popadł w biedę ${ }^{27}$.

Podstawowym zadaniem małżonków, zarówno religijnym, jak i społecznym, było zrodzenie i wychowanie potomstwa. W starożytności dzieci przedłużały życie rodziny, były jednym z podstawowych „dóbr” (zob. Ps 128,3 n), bez których człowiek i rodzina nie miały przyszłości. Brak dzieci, a szczególnie syna, był powodem smutku i cierpienia kobiety, traktowanym jako przejaw braku błogosławieństwa Bożego lub wprost przekleństwo (por. Jr 18,21) ${ }^{28}$. Także niepłodny mężczyzna, nadając przybranym synom takie same prawa, jakby byli z niego zrodzeni, ratuje się przed brakiem potomstwa, eunuch zaś z powodu utrwalonej bezpłodności jest w ogóle wyłączony z możliwości sprawowania kultu w Izraelu. Jedynym, który jest w stanie zaradzić w pełni niepłodności, jest Stwórca i to On pozwala urodzić synów niepłodnym kobietom, np. Sarze (Rdz $11,30 ; 16,1)$, Rebece ( $\operatorname{Rdz} 25,21)$ i Racheli ( $\operatorname{Rdz} 29,31)^{29}$. Małżeństwa były wielodzietne, a zadaniem rodziców było wdrożenie dzieci w życie wspólnoty, aby mogły podjąć przewidziane dla nich role społeczne, a przede wszystkim przekaz wiary przodków, która kształtowała tożsamość młodego pokolenia, konsolidując wspólnotę.

W przedstawionym kontekście Hanna nie jest typową dla swojej kultury kobietą, posiadanie tylko jednego dziecka było dla niej z pewnością powodem do zmartwienia, gdyż oznaczało również brak Bożego bło-

\footnotetext{
${ }^{25}$ W. Linke, Literacka ojczyzna, dz. cyt., s. 79 i 97.

26 Tamże, s. 83.

27 Tamże.

28 T. Twardziłowski, Zarys problematyki, dz. cyt., s. 112.

${ }^{29}$ E.G. Skóra, Seksualność, dz. cyt., s. 15.
} 
gosławieństwa. Z niemożnością posiadania potomstwa kobiety niekiedy radziły sobie, oddając mężowi jedną ze swoich niewolnic, aby chociaż ona zrodziła dzieci, prawdopodobnie jednak Tobiadzi nie byli na tyle dobrze sytuowani, aby stać ich było na posiadanie niewolnicy lub też zwyczaj ten nie był tak powszechny.

Księga Tobiasza ukazuje, jak na Hannę spadają ciosy: jeden za drugim. Najpierw jej rodzinę spotykają tarapaty finansowe: pogorszenie się sytuacji materialnej Tobita, które związane było z utratą prominentnej pozycji na dworze królewskim (Tb 1,16-20) ${ }^{30}$. Początkowo zubożałej rodzinie pomagał jeszcze krewny, ale z upływem czasu i jego pomoc ustała (Tb 2,10). Dodatkowo stały uszczerbek na zdrowiu w wyniku przykrego zdarzenia losowego wykluczył możliwość podejmowania przez Tobita jakiejkolwiek pracy oraz stworzył konieczność przejęcia przez Hannę odpowiedzialności za utrzymanie rodziny. Okoliczność podjęcia przez żonę pracy zarobkowej była uznawana za dyshonor dla męża, który nie potrafił utrzymać rodziny, dla żony zaś była to społeczna degradacja (por. Syr 25,22). Długi męża mogły skazać kobietę nawet na niewolnictwo, nie ma jednak pewności, że spotkało to Hannę (Tb 1,20 i 2.1), informacją potwierdzoną jest natomiast podjęcie przez nią pracy w zamian za wynagrodzenie.

Aktywność zawodowa kobiety była ograniczona do obrębu rodziny i dbania o dom, mogła ona podejmować drobne prace rzemieślnicze, jak np. tkanie czy wypiek chleba, wykonywane jednak w domu lub niekiedy na dworze królewskim ${ }^{31}$. Praca tkaczki, jaką wykonywała Hanna, nie była dobrze opłacana, tym bardziej że już w starożytności kobieta dostawała niższą od mężczyzny dniówkę za taką samą pracę. Jej zarobek stanowił jedyne źródło utrzymania całej rodziny, pracodawcami zaś mogli być Żydzi, którzy przez zatrudnienie pomagali ubogim pobratymcom ${ }^{32}$.

Jakby obciążeń fizycznych spowodowanych pogorszeniem się sytuacji życiowej było mało, do ciężaru związanego z opieką nad niepełnosprawnym mężem i ze świadczeniem dodatkowej pracy dochodzą

${ }^{30} \mathrm{M}$. Wojciechowski, To fight or not to fight? Various answers to the foreign political power in the Greek books of the Old Testament, „Folia Orientalia” 50 (2013), s. 247.

31 J. Slawik, O rolach kobiet, dz. cyt., s. 15.

${ }^{32}$ W. Linke, Literacka ojczyzna, dz. cyt., s. 201. 
cierpienia psychologiczne. Następnym ciosem, jaki spada na Hannę, jest konflikt ze współmałżonkiem. Do kłótni dochodzi z powodu otrzymanego w prezencie koźlęcia. Rodzinna sprzeczka wywiązuje się na podstawie posądzenia przez męża o kradzież (Tb 2,12-14). Oskarżenie, jakie wysuwa Tobit, bierze się być może z jego pobożności, a więc wstrętu do kradzieży, ale mogło również być pochodną złego nastroju, ślepota fizyczna wskazywałaby w tym wypadku na ślepotę rozumu ${ }^{33}$. Rozwój akcji wskazuje, że mąż w ogóle nie uwzględnia tłumaczeń żony, tylko wykłada swoje racje. Tobit nie tylko nie wierzy Hannie, ale wstydzi się za nią i żąda, żeby oddała koziołka właścicielom. Hanna broni się przez atak, krytykując męża i jego pobożność, która doprowadziła ich na skraj nędzy.

Opisana sytuacja jest świadectwem ubóstwa, w jakim żyła rodzina Tobiadów, skoro Tobit uważa artykuł spożywczy za rzecz mogącą wzbudzić tak wielkie pożądanie, że aż skłaniające do kradzieży, lub też świadczy o buncie i wstydzie powodowanym tym, że to żona zapewnia byt rodzinie. Mimo iż niepowodzenie ekonomiczne mogło być interpretowane jako brak Bożego błogosławieństwa, to jednak, ze względu na parenetyczny charakter księgi Tobiasza, mamy tutaj raczej do czynienia z portretem niewinnie cierpiącego sprawiedliwego, który jest ukazany na podobieństwo Hioba, przeciwko któremu zwróciła się nawet własna żona, pomnażając jego cierpienia, ukazane jako próba, która będzie przyczyną wywyższenia sprawiedliwego, a nie jako kara, która byłaby skutkiem występków. Jazgot pretensji Hanny jest kroplą przepełniającą czarę goryczy. Doprowadzony do skraju rozpaczy Tobit modli się o śmierć.

Ostatnim ciężarem, jaki przygniata Hannę, jest rozstanie z synem, które mocno przeżywa. Żegnając syna, kobieta być może żegnała się tym samym z jedynym zabezpieczeniem na stare lata, a zostawała u boku kalekiego męża, którego musiała utrzymywać. Inaczej niż w dobie opiekuńczego państwa i ubezpieczeń społecznych, w starożytności jedynie dzieci gwarantowały pogodną starość rodziców, były także polisą ubezpieczeniową od wypadków losowych. W przypadku wdowieństwa po śmierci ojca na synu spoczywał obowiązek opieki i utrzymania matki. Podobnie syn Tobita miał przykazane, by matki nie porzucał i nie zaniedbywał ekonomicznie, gdyż jako wdowa nie miałaby się z czego utrzymać

${ }^{33}$ M. Wojciechowski, Księga Tobiasza, czyli Tobita, dz. cyt., s. 66. 
(Tb 4,3-4). Pożegnanie z synem wskazuje na złożone motywacje, jakie mogły Hanną kierować, być może jej osobowość także była złożona.

Dialog Hanny z Tobitem pogłębia charakterystykę postaci i z psychologicznym realizmem ukazuje niepokoje matki ujawniające się w rozmowie z mężem. Miłość Hanny do jedynego syna jest autentyczna, pogoń zaś za majątkiem i związane z nią ryzyko wydają się jej zbyt dużą ceną, skoro można poprzestać na skromnej, acz spokojnej egzystencji. Decyzja Tobita o wyprawieniu syna w podróż słusznie zatem budzi niepokój Hanny, a jej obawy są racjonalnie uzasadnione, jednak jej emocjonalna reakcja została potraktowana jako zachowanie typowo kobiece, w sensie pejoratywnym, tzn. słabość, niezrównoważenie, bojaźliwość itp. Zachowawcza, czy lękliwa postawa kobiety kontrastuje z odważną postawą Tobita, który ją pociesza, czule nazywając siostrą ${ }^{34}$.

Trudno sobie wyobrazić, jak ciężkie życie wiodła Hanna, zmagając się o przeżycie i mając za jedyne towarzystwo utyskującego męża, nie dziwi zatem fakt, że oczekiwała $\mathrm{z}$ utęsknieniem powrotu syna. Jego przedłużająca się nieobecność sprawiła, że Tobit zaczął się martwić, a Hanna nawet rozpaczać, wyobrażając sobie najgorsze scenariusze oraz wyrzucać sobie, że dopuszczając do podróży, niepotrzebnie wystawiła syna na niebezpieczeństwo. Zrozpaczona kobieta była nieutulona w swoim żalu i nikomu nie dawała się pocieszyć (Tb 10,4-7). Jednakowoż, wbrew własnym emocjom i wyobraźni, uporczywie tliła się w niej jakaś iskra nadziei, gdyż wychodziła codziennie na drogę, aby wyglądać powrotu syna i płakać nad swoją niedolą. Miotające nią sprzeczne uczucia symbolicznie podkreślają wzmianki o świetle słońca i nocy. Można zdiagnozować jej stan jako wielki smutek, skłaniający się w kierunku żałoby z powodu projekcji śmierci własnego dziecka. Może nawet cierpiała na depresję wywołaną całokształtem sytuacji rodzinnej, w który wpisywała się domniemana śmierć syna, utrata wcześniejszej pozycji, konflikt z mężem i ciężka praca fizyczna. Stereotyp kobiecego zachowania jest wyeksponowany przez kontrast $\mathrm{z}$ męskim stereotypem uosabianym przez Tobita, mocnego i pocieszającego żonę ${ }^{35}$. Wielka miłość Hanny i trud oczekiwania zostają w końcu nagrodzone, kiedy widzi całego i zdrowego syna powracającego do domu

${ }^{34}$ M. Wojciechowski, Księga Tobiasza, czyli Tobita, dz. cyt., s. 93-94.

${ }_{35}$ Tamże, s. 119-120. 
z dalekiej podróży. Hanna jakby się zmienia, przechodząc ze smutku, załamania do wybuchu radości. Zmiana usposobienia Hanny wskazuje na dynamizm jej osobowości. Radość kobiety jest tym większa, bo syn wykonał powierzone mu zadanie. Podróż zakończyła się sukcesem ekonomicznym: syn przywiózł odzyskane pieniądze, będzie mógł zatem przyjść $\mathrm{z}$ pomocą rodzicom znajdującym się w potrzebie. Jakby tego jeszcze było mało, Tobiasz wrócił nie tylko $\mathrm{z}$ pieniędzmi, ale dodatkowo z żoną i to z rodu ojca, jak nakazuje reguła endogamii, a oprócz żony przywiózł także lekarstwo na ślepotę ojca, które okazało się skuteczne. Hanna z nadmiaru szczęścia deklaruje gotowość na śmierć. Deklarację tę należy interpretować w kontekście faktów, a więc jako wyraz poczucia spełnienia swojej misji życiowej, zamiast doszukiwać się symptomów psychicznej choroby dwubiegunowej przechodzącej od depresji do euforii. Perypetie rodziny Tobiadów kończą się zatem happy endem.

\section{EDNA, ŻONA RAGUELA, MATKA SARY I TEŚCIOWA TOBIASZA}

Ednę poznajemy we wnętrzu typowego zamożnego domu miejskiego w Ekbatanie. Imię Edna ma znaczenie 'zmysłowa, przyjemna', tak jak Eden ${ }^{36}$. Edna jest żoną Raguela i, podobnie jak Hanna, jest matką jedynego dziecka, a co gorsza: córki - Sary. Fakt ten był powodem do zmartwień, gdyż - jak to już zostało zasygnalizowane - w starożytności bezpłodność była odczytywana jako brak łaski Bożej i znak przekleństwa, do tego brak męskiego potomka: dziedzica i opiekuna nie wróżył nic dobrego na starość ${ }^{37}$. Kolejnym problemem Edny jest fiasko starań wydania córki za mąż. Brak sukcesów na niwie matrymonialnej mogła odbierać

${ }^{36}$ A. Calmet, Dictionnaire historique, critique, chronologique, géographique et littéral de la Bible, t. 4, Genewa 1730, s. 71; por. B. Bow, G.W.E. Nickelsburg, Patriarchy with a Twist: Men and Women in Tobit, w: Women Like This: New Perspectives on Jewish Women in the Greco-Roman World, red. A.-J. Levine, Atlanta 1991, s. 127-143.

37 J.A. Gladson, The role of women in the Old Testament outside the Pentateuch, s. 3-4, źródła internetowe: https://www.adventistarchives.org/the-role-of-women-inthe-old-testatment-outside-the-pentateuch.pdf, [dostęp: 28.02.2017]; por. M.J. Guevara Llaguno, Modelos de mujer en la historia deuteronomista: excusa, legitimación y propaganda - Feminine roles models in Deuteronomistic History, „MEAH sección Hebreo” 58 (2009), s. 116. 
jako własną porażkę wychowawczą, bo obowiązkiem matki było przygotowanie córki do podjęcia ról społecznych dla niej przewidzianych ${ }^{38}$.

Kiedy Edna wita gości przyprowadzonych do domu przez męża, dość swobodnie z nimi rozmawia (Tb7,2-3). Przejmuje ona rolę przewidzianą $\mathrm{z}$ reguły dla męża, w czym można upatrywać znamion półpatriarchatu. Edna prowadzi konwencjonalną konwersację, w toku której dowiaduje się, kim są przybysze. Razem z mężem poddają się wzruszeniu, kiedy poznają, że goście, którzy niespodziewanie się pojawili w ich domu, są ich krewnymi.

Dalej Edna jest przedstawiona jako dobra żona, posłusznie wykonująca polecenia męża i zajmująca się pracami domowymi: ścieleniem łóżka, pieczeniem chleba - wszystkie te zajęcia są tradycyjnie przypisywane kobiecie. Edna jest też wyraźnie odpowiedzialna za zarządzanie służącymi, gdyż Raguel nie wydaje poleceń bezpośrednio, ale zleca żonie zadysponowanie służącą w celu sprawdzenia, czy nowożeńcy przeżyli noc poślubną. Z faktu posiadania służącej można wysnuć wniosek, że rodzina Ekbatany jest bardziej majętna niż ta mieszkająca w Niniwie, z której pochodzi Tobiasz.

Fabuła księgi Tobiasza jest wrażliwa na uczucia kobiet. Po przygotowaniu sypialni dla młodych Edna ze łzami w oczach zwraca się do córki: „Ufaj, córko, Pan nieba obdarzy cię radością w miejsce twego smutku. Ufaj, córko!” (Tb7,16), co jest przeciwieństwem cytatu z księgi Amosa (Am 8,9-10), jakby pozytywnym proroctwem na przyszłość córki ${ }^{39}$. W ten sposób matka podtrzymuje na duchu córkę. Płacz, oprócz wyrażania miłości i przywiązania, mógł też zwyczajowo towarzyszyć obrzędowi małżeństwa, które oznaczało rozstanie panny młodej z rodziną wyjściową, a więc szokującą zmianę dotychczasowego status quo, dlatego w kategoriach religioznawczych małżeństwo jest nazywane „rytem przejścia” ${ }^{40}$.

Po zaślubinach, kiedy młodzi małżonkowie zbierają się do opuszczenia rodziny panny młodej, Edna błogosławi Tobiaszowi na droge jak własnemu synowi. Jednocześnie daje wyraz swojej macierzyńskiej troskli-

38 E. Limentani, Il Ruolo della donna, dz. cyt.

${ }^{39}$ L. Stuckenbruck, The Book of Tobit: A Very Short Commentary with English Translation, źródła internetowe: http://www.academia.edu/19883995/Tobit_-_A_very_ short_commentary_with_translation [dostęp: 28.02.2017].

${ }^{40}$ M. Wojciechowski, Księga Tobiasza, czyli Tobita, dz. cyt., s. 109. 
wości, zabezpieczając przyszłość córki przez wyrażenie życzenia, by Tobiasz nigdy jej nie zasmucał. Następnie dokonuje się słowne poszerzenie rodzicielstwa na teściów, które wyraża się we wskazaniu, że Tobiasz jest synem Edny, a ona jego matką, oraz że teściowie Sary są jej rodzicami (Tb 10), co znowu wskazuje na aspekt nierozerwalności małżeństwa. W wielopokoleniowej rodzinie mieszkającej pod jednym dachem każdy domownik miał określoną rolę. Teściowie, przyjmujący pod swój dach współmałżonka swojego dziecka, przejmowali wobec niego rolę rodziców, a starsze kobiety przekazywały swoją mądrość życiową i doświadczenie młodszym. Relacja z teściami jest ukazana w księdze Tobiasza w sposób pozytywny, jako mająca zakotwiczenie w kontekście uporządkowanych zwyczajów społecznych. Mąż wprowadzał żonę do swojego domu i do swojej rodziny.

$\mathrm{Na}$ końcu następuje pożegnanie z Sarą i Tobiaszem, czemu towarzyszy wypowiedziane przez Ednę pragnienie powtórnego spotkania oraz poznania wnuków, kiedy już się pojawią. Jest to protokół zachowań społecznych zbieżny z polską tradycją kulturową, która również zaleca małżonkom zwracanie się do teściów jak do swoich rodziców, dziadków natomiast czynnie angażuje w wychowaniu wnuków. Niekiedy zdarza się, że tworzą oni wielopokoleniową rodzinę mieszkającą pod jednym dachem. Zwyczaje te być może są inspirowane księgą Tobiasza.

W świetle narracji Edna okazuje się osobą raczej prostolinijną, która wyrażając siebie, działa w granicach ówcześnie przyjętych konwencji. Jest dobrą matką pragnącą szczęścia swojego dziecka, które widzi w małżeństwie, gdyż takie jest jej własne doświadczenie życiowe, a także kontekst kulturowy. Pragnie ona także przedłużenia radości macierzyństwa przez doświadczenie bycia babcią. Odnośnie do relacji małżeńskiej można powiedzieć, że był to raczej spokojny związek. Ze szczegółów, jakie księga Tobiasza eksponuje, wynurza się obraz osoby stabilnej, czy nawet statycznej, która odgrywa rolę bohaterki drugiego planu.

\section{ZAKOŃCZENIE}

W społeczeństwie, w którym kobiety miały niewiele praw i odgrywały raczej podrzędną rolę, ograniczającą się do przestrzeni życia domowego, Biblia maluje wyjątkowe portrety kobiet oddanych rodzinie, 
pracowitych, zarządzających domem, mądrych oraz emocjonalnych. Ideałem wyłaniającym się z księgi Tobiasza jest dojrzała, doświadczona i raczej starsza kobieta, która „otwiera usta z mądrością, na języku jej miłe nauki. Bada bieg spraw domowych, nie jada chleba lenistwa. Powstają synowie, by szczęście jej uznać, i mąż, ażeby ją sławić” (Prz 31,26-28).

Właśnie w ten sposób przedstawione są bohaterki księgi Tobiasza: Debora, Hanna i Edna, kobiety dojrzałe, mądre i troskliwe. Są one ukazane w kontekście rodziny, gdyż na niej koncentrowało się życie społeczne w starożytności. Kobiety występują w narracji starożytnej w rolach córek, żon, matek, teściowych i babek, częściej są też pokazywane wśród rodziny, raczej w domu, niż poza nim, na zewnątrz czy wśród obcych. W księdze Tobiasza ich osobowość jest oddana z pełnym realizmem psychologicznym, bez tuszowania niedoskonałości. Można doszukiwać się w nich rysów miłosierdzia, które jest jednym z głównych wątków tej księgi.

Akcja księgi Tobiasza ujawnia swoistą teologię narracyjną, wydarzenia malują obraz Boga, który jako „miłosierny Bóg Zbawca jest również Bogiem uzdrawiającym (Tb 5,10), wspomożycielem, opiekunem (Jdt 9,11) jednostek i całego narodu"41. Miłosierdzie, jako przymiot boski jest i powinno być naśladowane, dlatego główny bohater księgi - Tobit okazuje współczucie przez dobroczynność. Czyn miłosierdzia, jakim jest jałmużna, ma związek ze sprawiedliwością, gdyż „jałmużna uwalnia od śmierci i oczyszcza z każdego grzechu" (Tb 12,9; por. Prz 10,2; 11,4; Syr 29,10-13; 40; 24; Dn 4,24). Miłosierdzie można także zauważyć zarówno w postawie, jak i w posłudze ukazanych w tej księdze kobiet. Dobroczynność względem innych jest niejako wpisana w istotę ich powołania, a miłosierdzie niewiasty, która „otwiera dłoń ubogiemu, do nędzarza wyciąga swe ręce” (Prz 31,20) promieniuje dobrem daleko poza krąg rodzinny. Jednak w przypadku kobiet, miłosierdzie względem innych nie rzuca się w oczy, gdyż łączą one cnotę miłosierdzia z podstawowymi potrzebami życiowymi. One karmią głodnego, odziewają nagiego, przybysza w dom przyjmują, strapionego pocieszają, dbają o chorego i kalekę, a więc wykonują konkretną pracę. „W tym się zawiera cała miłość. Łączy ona

${ }^{41}$ R. Pietkiewicz, Obraz Boga $w$ deuterokanonicznej historiografi Starego Testamentu, „Świdnickie Studia Teologiczne” 7 (2010) 7, s. 258; M. Wojciechowski, Księga Tobiasza, czyli Tobita, dz. cyt., s. 41. 
skończoność i nieskończoność, wymiar cielesny i duchowy. Nie chodzi tutaj o dobre uczucia, ale o realizm" ${ }^{42}$.

Duchowość kobiety, jak ją ukazuje księga Tobiasza, jest mocno zakorzeniona w rzeczywistości życia i ma charakter inkarnacyjny, tak też jest ona ogólnie przedstawiane w Biblii. Nie dziwi zatem fakt, że wizje profetyczne właśnie do kobiety porównują cały naród wybrany, a szczególnie Jerozolimę, jego symbol. Porównanie to jest tym bardziej sugestywne, iż prorocy, obserwując życie kobiet: całkowicie oddane i zanurzone w życiodajnej relacji małżeńskiej, widzą w nim odzwierciedlenie relacji Boga z człowiekiem. Bóg bogaty w miłosierdzie powołuje człowieka do bytu w świecie i darzy go miłością, która nie tylko stwarza dobro, ale doprowadza do uczestnictwa we własnym życiu Boga ${ }^{43}$. Każdy, na podobieństwo biblijnych kobiet, ma możliwość zaangażowania się w tę życiodajną per se relację, wyrażającą się w konkretnych realiach życia czynami miłosierdzia, gdyż kto miłuje, pragnie obdarzać sobą.

Streszczenie. W społeczeństwie patriarchalnym Imperium Asyrii i Medii ok. IV w. przed Chr. kobiety diaspory żydowskiej są ukazywane w kontekście rodziny, w domu, w rolach podporząakowanych córek, żon, matek, teściowych i babek. Księga Tobiasza z pełnym realizmem i bez retuszowania niedoskonałości przedstawia portrety trzech starszych i doświadczonych kobiet: Debory, Hanny i Edny. Uosabiają one ideał kobiety oddanej rodzinie, pracowitej, dobrze zarządzającej domem, mądrej i emocjonalnej.

Jednym z głównych wątków księgi jest miłosierdzie Boże. Bóg bogaty w miłosierdzie doprowadza do uczestnictwa we własnym życiu swoich naśladowców, w tym współczujące i dobroczynne kobiety. Miłosierdzie stanowi istotę ich powołania, jednak przejawy ich dobroczynności nie rzucają się w oczy, gdyż są związane z podstawowymi potrzebami życiowymi. To one karmią, odziewają, udzielają gościny, pocieszają i pielęgnują. Powołanie kobiety ma zatem charakter inkarnacyjny i dlatego kobieta uosabia w Biblii naród wybrany, a więc każdego człowieka w relacji do Boga, ukazując możliwość odpowiedzi Bogu w realiach codziennego życia, bo kto miłuje, pragnie obdarzać sobą.

Słowa kluczowe: Księga Tobiasza; starsza kobieta; miłosierdzie.

${ }^{42}$ F. Hadjadj, La sagesse de la charité, une spiritualité de lincarnation, źródła internetowe: https://fr.zenit.org/articles/la-sagesse-de-la-charite-une-spiritualite-de-lincarnation-par-fabrice-hadjadj/, [dostęp: 28.02.2017].

${ }^{43}$ Jan Paweł II, Encyklika Dives in misericordia, Rzym 30.11.1980, 7; por. tamże 2, 9, 14, źródła internetowe: http://w2.vatican.va/content/john-paul-ii/pl/encyclicals/documents/hf_jp-ii_enc_30111980_dives-in-misericordia.html [dostęp: 28.02.2017]. 
Abstract. Aging women and Their Spirituality in the Book of Tobit. In the patriarchal society of the Assyrian and Medes Empire of the $4^{\text {th }}$ century BC, women from the Jewish Diaspora are depicted in the context of the family, at home, in the subordinated roles of daughters, wives, mothers, grandmothers and mothers in law. Without retouching their imperfections the book of Tobit with portrays full realism three experienced and aging women: Deborah, Hanna and Edna. They embody the ideal of woman: devoted to the family, hard-working, good manager of the household, wise and emotional.

One of the main topics in the book of Tobit is the Divine Mercy. God is rich in mercy and he grants participation in his very life to those who follow him - including compassionate and charitable women. Mercy is very heart of their vocation, but their charity's manifestations are somehow hidden, as they are linked to the fundamental needs of life: they feed, clothe, welcome, console and take care. The vocation of women has an incarnational character: this is why the woman symbolises in the Bible God's relationship with man and the possibility of answering God in a daily life reality, for he who loves desires to give himself.

Key words: Book of Tobit; aging women; mercy.

\section{BIBLIOGRAFIA}

Balldock, J., Kobiety w Biblii, Warszawa 2008.

Brown Tkacz, C., Are Old Testament Women Nameless, Silent, Passive Victims?, "This Rock" 17 (2006) 10, źródła internetowe: http://www.catholic.com/magazine/articles/ are-old-testament-women-nameless-silent-passive-victims [dostęp: 28.02.2017].

Bow, B., Nickelsburg, G. W. E., Patriarchy with a Twist: Men and Women in Tobit, w: Women Like This: New Perspectives on Jewish Women in the Greco-Roman World, red. A.L. Levine, Atlanta: 1991,ss. 127-143.

Bauckham, R., Tobit, as a parable for the exiles of Northern Israel, w: Studies in the Book of Tobit: A Multidisciplinary Approach, red. M. Bredinss, London 2006, s. 140-164.

Calmet, A., Dictionnaire historique, critique, chronologique, géographique et littéral de la Bible, t. 4, Genewa 1730.

Chrostowski, W., Rzeczywistość i symbolika kobiety w Biblii, „Pastores” 14 (2002) 1, s. 9-21.

Gladson, J. A., The role of women in the Old Testament outside the Pentateuch, s. 3-4, źródła internetowe: https://www.adventistarchives.org/the-role-of-women-in-theold-testatment-outside-the-pentateuch.pdf [dostęp: 28.02.2017].

Guevara Llaguno, M. J., Modelos de mujer en la historia deuteronomista: excusa, legitimación y propaganda - Feminine roles models in Deuteronomistic History, „MEAH sección Hebreo" 58 (2009), s. 113-138.

Hadjadj, F., La sagesse de la charité, une spiritualité de l'incarnation, źródła internetowe: https://fr.zenit.org/articles/la-sagesse-de-la-charite-une-spiritualite-delincarnation-par-fabrice-hadjadj/ [dostęp: 28.02.2017]. 
Jackobs, N., You didnot hesitate to get up and leave the dinner - Food and eating in the narrative of Tobit with some attention to Tobit's Shavuot Meal, w: The book of Tobit: Text, Tradition, Theology, red. G. G. Xeravits, J. Zsengellér, Pápa 2004, s. 121-138.

Jan Paweł II, Encyklika Dives in misericordia, Rzym 30.11.1980, źródła internetowe: http://w2.vatican.va/content/john-paul-ii/pl/encyclicals/documents/hf_jp-ii_ enc_30111980_dives-in-misericordia.html [dostęp: 28.02.2017].

Limentani, E., Il Ruolo della donna nella tradizione ebraica. Beve panorama storico-sociale, źródła internetowe: http://www.babelonline.net/home/003/ventaglio/Limentani_rulo_donna.pdf [dostęp: 28.02.2017].

Linke, W., Literacka ojczyzna Tobiasza. Tło kulturowe Tb jako klucz teologicznej lektury księgi, Warszawa 2013.

Linke, W., Małżeństwo Tobiasza i Sary w księdze Tobiasza. Przyczynek do historii instytucji małżenstwa, „Collectanea Theologica” 79 (2009) 4, s. 31-45.

Nowell, I., Roles of Women in the Old Testament, źródła internetowe: http://www.laici.va/ content/dam/laici/documenti/donna/bibbia/english/roles-women-old-testament. pdf [dostęp: 28.02.2017].

Pietkiewicz, R., Obraz Boga w deuterokanonicznej historiografii Starego Testamentu, „Świdnickie Studia Teologiczne” 7 (2010) 7, s. 247-264.

Proc, B., Wpływy perskie w księdze Tobiasza, „Scripta Biblica et Orientalia” 3 (2011), s. 183-190.

Przygoda, W., Miłosierni jak Ojciec. Teologia i praktyka miłosierdzia chrześcijańskiego, Współczesne wyzwania Teologii Pastoralnej, red. R. Chałupniak, J. Kostorz, Opole 2016, s. 9-20.

Rose, M., Une herméneutique de l'Ancien Testament: comprendre, se comprendre, faire comprendre, Genewa 2003.

Skóra, E. G., Seksualność człowieka jako mężczyzny i kobiety na tle Starego Testamentu, „Kwartalnik Naukowy Towarzystwa Naukowego Fides et Ratio” 4 (2014) 20, s. 6-23.

Slawik, J., O rolach kobiet w Starym Testamencie (Biblii Hebrajskiej), „Rocznik Teologiczny ChAT" 54 (2012) 1-2, s. 9-30.

Stuckenbruck, L., The Book of Tobit: A Very Short Commentary with English Translation, źródła internetowe: http://www.academia.edu/19883995/Tobit_-_A_very_short_ commentary_with_translation [dostęp: 28.02.2017].

Twardziłowski, T., Zarys problematyki rodzinnej w Biblii, w: Instytucja rodziny wczoraj i dziś - Perspektywa interdyscyplinarna, T. 2: Społeczeństwo i kultura, red. J. K. Stępkowska, K. M. Stępkowska, Lublin 2012, s. 11-120.

Wojciechowski, M., Księga Tobiasza, czyli Tobita. Opowieść o miłości rodzinnej, Częstochowa 2005.

Wojciechowski, M., Nauczanie moralne greckich ksiag Starego Testamentu, „Analecta Biblica Lublinensia" 7 (2011), s. 99-110. 
Wojciechowski, M., To fight or not to fight? Various answers to the foreign political power in the Greek books of the Old Testament, „Folia Orientalia” 50 (2013), s. 243-254.

Zielonka, I., Kobiety sławione pieśnia w Starym Testamencie - Debora i Jael, „Collectanea Theologica" 81 (2011) 1, s. 17-39.

Ziółkowski, Z., Z najtrudniejszych stronnic w Biblii - Zmiana w Zdrowaśce, w: Najtrudniejsze stronice Nowego Testamentu, Warszawa 2006, s. 773-778. 